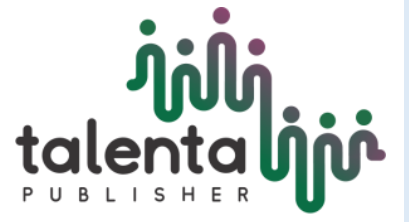

Intepกลนกำล ปoupmal of Ecophysiology

\title{
Chrome Analysis on Lichens at Ambient Air On Living Trees
}

\author{
Ashar Hasairin $^{1^{*}}$ and Rosliana Siregar ${ }^{2}$ \\ ${ }^{1}$ Biology Department, Faculty of Mathematics and Natural Sciences Universitas Negeri Medan \\ ${ }^{2}$ Teaching staff Universitas Islam Sumatera Utara
}

\begin{abstract}
The purpose of this study was to analyze the amount of chrome in lichens live on living tree Mahoni (Swietenia macrophylla) at ambien air in Pinang Baris Bus Station Medan. Purposive sampling method was conducted. The analitical data used was corelations product moment. Results showed 5 species of lichens were identified. Each the species contain $\mathrm{Cr}$ and Ocrolechia tartarea was the highest. Ambien weather at the atmosphere consists of $\mathrm{NO}_{2} 22.21 \mu \mathrm{g} / \mathrm{m}^{3}, \mathrm{SO}_{2} 16.29 \mu \mathrm{g} / \mathrm{m}^{3}, \mathrm{CO} 11 \mathrm{ppm}, \mathrm{H}_{2} \mathrm{~S} 0,00883 \mathrm{ppm}$ and $\mathrm{O}_{3} 76.01 \mu \mathrm{gg} / \mathrm{m}^{3}$. Temperatur $32.34{ }^{\circ} \mathrm{C}$, relative humidity $69 \%$, light instensity 500 Joule and wind speed $2,1 \mathrm{~m} / \mathrm{s}$. Corelations chrome lichens to the ambien air showed result 0,15 is very low. Corelation lichens value to the ambien air is $-0,13$. Showed negatif and it is not significan and very low.
\end{abstract}

Keywords: chrome, lichens, ambient air

Received 1 June 2019| Revised 1 July 2019| Accepted 31 August 2019

\section{Introduction}

Lichens are one of the organisms that are used as bioindicators of air pollution. This is because lichens are very sensitive to air pollution, have a wide geographical distribution (except in waters), abundant presence, sessile, perennial, have a relatively fixed morphological form for a long period of time and do not have a cuticle layer so that lichens can absorb gas and pollutant particles directly through the surface of their thallus. The use of lichens as a bioindicator is considered to be more efficient than using an ambient indicator device or machine which requires large costs in its operation (Loopi et al, 2002).

Chrome (Cr) is a type of metal that is often used as a vehicle exhaust coating. Chrome can be released into the atmosphere along with motor vehicle emissions, especially those with diesel fuel (Bajpai et al, 2011). Chrome is heavy metal pollutant that toxic and can cause

*Corresponding author at: Faculty of Mathematics and Natural Sciences, Universitas Negeri Medan, Medan, Indonesia

E-mail address: nst.ashar@yahoo.com 
respiratory problems and other diseases if absorbed by humans (Panjaitan et al, 2012). Furthermore Jovan (Jovan, 2014) stated that the presence of pollutants in the air endanger living things including humans. Therefore, efforts to monitor air quality, especially in residential environments are very necessary. Air quality monitoring can be done by using an air quality monitoring device or by conducting biomonitoring on the presence of a bioindicator in the environment. Lichens is one of the organisms used as bioindicators of air pollution. Lichen is very sensitive to air pollution, their thallus are able to absorb gases and pollutant particles directly through the surface of the thallus. The purpose of research was to study of $\mathrm{Cr}$ in lichens found at ambient air living on standing trees.

\section{Materials and Methods}

This research was conducted in Pinang Baris bus station and Medan Health Laboratory Center. All types of lichens in the living trees were analyzed chromic compounds was analyzed using atomic absorption spectrophotometry (AAS). Cr correlation on the thallus of lichens with ambient air was carried out using product moment correlation analysis in the SPSS 20 program.

\section{Result and Discussion}

Five types of lichens found can be seen in Table 1.

Table 1. Species of lichenes, type of their thallus and colony found in standing tree

\begin{tabular}{cclc}
\hline No & \multicolumn{1}{c}{ Species } & Thallus type & Colony number \\
\hline 1 & Rhizocarpon geograficum & Crustose & 6 \\
2 & Ochrolechia tartarea & Crustose & 4 \\
3 & Buellia canescens & Foliose & 17 \\
4 & Parmelia saxatilis & Foliose & 51 \\
5 & Graphis cripta & Crustose & 4 \\
\hline
\end{tabular}

Table 1 showed that the predominance lichens in the mahogany tree is Parmelia saxatilis. Each type of lichens has vary in their morphological characteristics. According to Panjaitan (2012) the level of traffic density has an effect on lichens diversity in shade trees. The lower the level of traffic density, the higher the diversity of Lichens species found in a location, and vice versa. 
The number and type of lichens varies greatly, each type of lichens found have characteristics that vary from one species to another, this can be observed from their type of thallus, shape, color, surface, and other characteristics. The body of the lichens is called the thallus which is vegetatively similar to algae and fungi (Hasairin, 2014).

Three types of lichens crustase type (Rhizocarpon geograficum, Ochrolecia tartarea, and graphis cripta. Foliose types (Buellia canescens and Parmelia saxatilis). The most common type of lichens found was foliose type, but the colonies with the crustase type dominate the mahogany tree stand at the study site. A similar results was also reported by Hasairin (2014). He reported that crustose type were the common type found. Crustose types are more resistant to other types. Crustose is smaller, thinner, firmly attached to corticoleus (tree bark). Crustose has been used in Japan as a bioindicator of air pollution. Hasairin (2014) said that crustose types were considered more tolerant of air pollution because they had a relatively simple thallus structure compared to other types. Lichens are tolerant in areas with polluted air conditions. However, for the number of colonies that most dominate the stands of mahogany trees are lichens with foliose type.

After analyzing the levels of $\mathrm{Cr}$ (chromium) Lichens found in mahogany tree stands, it can be seen in Table 2.

Table 2. Concentration of $\mathrm{Cr}$ thallus of lichens

\begin{tabular}{clcc}
\hline No & \multicolumn{1}{c}{ Species of lichens } & weight $(\mathbf{g})$ & Cr concentration $(\boldsymbol{\mu g} / \mathbf{m l})$ \\
\hline 1 & Rhizocarpon geograficum & 1,02 & 70,63 \\
2 & Ochrolechia tartarea & 1,02 & 107,6 \\
3 & Buellia canescens & 1,04 & 27,83 \\
4 & Parmelia saxatilis & 1,03 & 21,50 \\
& & 1,03 & 11,21 \\
\hline
\end{tabular}

In Table 2 showed five types of lichens measured by $\mathrm{Cr}$ levels where each type has different levels of the five types of lichens $\mathrm{Cr}$ (Chrom) levels are highest in the type of Ochrolechia tartarea which has thallus crustose type of $107.6 \mu \mathrm{g} / \mathrm{ml}$. The metal absorbed by the lichens accumulates in the thallus tissue. The thallus structure is one of the factors that influence the 
efficiency of metal absorption (Hasairin, 2014). The broad thallus surface causes foliose lichens to have greater contact with pollutants so that accumulation of pollutants is more efficient than other thallus types. Determination of metal concentration generally uses a bioindicator approach to metal pollution by utilizing lichens. While Jamhari (2010) reported that morphology and physiology of lichens is considered relevant to metal accumulation. Some common metals include lead $(\mathrm{Pb})$, Cadmium $(\mathrm{Cd})$, Chromium $(\mathrm{Cr})$, Zinc $(\mathrm{Zn})$ and Copper $(\mathrm{Cu})$.

Ambient air content $\left(\mathrm{NO}_{2}, \mathrm{SO}_{2}, \mathrm{CO}\right.$, and $\mathrm{H}_{2} \mathrm{~S}$, and $\left.\mathrm{O}_{3}\right)$ in the Pinang Baris bus station can be seen in Table 3:

Table 3. Ambient air on Pinang Baris bus station area

\begin{tabular}{cccc}
\hline Gases & concentration & unit & Method \\
\hline $\mathrm{NO}_{2}$ & 22.21 & $\mu \mathrm{g} / \mathrm{m}^{3}$ & Griez Saltzman \\
$\mathrm{SO}_{2}$ & 16.29 & $\mu \mathrm{g} / \mathrm{m}^{3}$ & Pararosanilin \\
$\mathrm{CO}$ & 11 & $\mathrm{Ppm}$ & NDIR \\
$\mathrm{H}_{2} \mathrm{~S}$ & 0,00883 & $\mathrm{ppm}$ & Methylene Blue \\
$\mathrm{O}_{3}$ & 76.01 & $\mu \mathrm{g} / \mathrm{m}^{3}$ & Chemeluminescnt \\
\hline
\end{tabular}

Ambient air measurements at the location of the study are intended to determine the level of pollution. Ambient air extraction is carried out during the day at 10:00 to 11:00 a.m. Transportation activities are thought to contribute to ambient air and the surrounding environment (Hasairin, 2014). Measuring the value of the content of ambient air samples with the parameters of $\mathrm{CO}, \mathrm{CO}_{2}, \mathrm{NO}_{2}, \mathrm{SO}_{2}$ and $\mathrm{O}_{3}$ is still far below the ambient air quality standard according to Government Regulations PP No. 41 of 1999. Observation of habitat characteristics or environmental physical-chemical conditions carried out in this study are temperature, humidity, wind speed and light intensity. This measurement was carried out only once at the study site. The physical-chemical conditions of the environment at the study site can be seen in Table 4. 
Table 4. Environmental characteristics Pinang Baris bus station area

\section{Environmental factors}

Temperature

Relative humidity

Light intensity

Wind speed $32.34\left({ }^{\circ} \mathrm{C}\right)$

$69 \quad(\%)$

500 (Joule)

$2,1 \quad(\mathrm{~m} / \mathrm{s})$

Microclimate conditions in the Pinang Baris Terminal area with a temperature of $32.34{ }^{\circ} \mathrm{C}$, air humidity $69 \%$, light intensity 500 Joules and wind speed $2.1 \mathrm{~m} / \mathrm{s}$. This supports the opinion of Noer (2014) that lichens are able to grow at dry places with relative humidity of $40 \%-69 \%$. The correlation analysis (r) of $\mathrm{Cr}$ showed positive with value 0.15 , very low level and not significant. The level of relationship is very low in the correlation value of 0.15 indicates a positive and insignificant presence. Analysis of Cr Correlation in thallus of lichens with ambient air is very low. Positive correlation indicates that there is a relationship between $\mathrm{Cr}$ in the thallus of lichens and ambient air, which means that the higher $\mathrm{Cr}$ levels in the thallus of lichens, the higher the level of ambient air. The negative correlation shows the fewer number of lichens, the higher the level of ambient air.

\section{Conclussion}

Analysis of lichens correlation at ambient air has a negative and non-significant existence.

\section{References}

[1] Bajpai R, Mishra GK, Mohabes, Upreti DK, Nayaka S. Determination of Atmospheric heavy metals using two lichens species in Katni and Rewa cities. 2011, Journal of Environmental Biology 32, India.

[2] Hasairin, A. Jenis-Jenis Lichens Di Kota Medan Sebagai Bioindikator Kualitas Udara, Makalah Semirata PTN Wilayah Barat. 2014, IPB, Bogor.

[3] Jamhari, M. Hubungan Kandungan Timbal $(\mathrm{Pb})$ di Udara dengan $\mathrm{Pb}$ Dalam Talus Lichens Xanthoparmelia xanthofarinosa. Makalah Seminar Nasional VIII Pendidikan Biologi, 2010.

[4] Jovan, S. Lichens Bioindication of biodiversity, air quality, and climate : baseline results from monitoring in Washington, Oregon, and California. 2008, 
Gen. Tech. Rep. PNW-GTR-737. Portland, OR: U.S Department of Agriculture, Forest Service, Pacific Northwest Research Station.

[5] Loopi S, Ivanov D, Boccardi R. Biodiversity of Epiphytic Lichens and Air Pollution in the Town of Siena Central Italy. 2002, Environmental Pollution.

[6] Noer, I. S. Bioindikator Sebagai Alat Untuk Menengarai Adanya Pencemaran Udara. Forum Komunikasi Lingkungan III. 2004, Kamojang, Bandung.

[7] Panjaitan, D.M., Fitmawati, Atria, M. Keanekaragaman Lichens Sebagai Bioindikator Pencemaran Udara Di Kota Pekanbaru Provinsi Riau, FMIPA Universitas Riau, Riau. 2012. 